\title{
Economic performance of the "Emping Melinjo" household industry and the entrepreneurial character of the business owner
}

\author{
Triwara Buddhi Satyarini* \\ Department of Agribusiness, Faculty of Agriculture, Universitas Muhammadiyah Yogyakarta, \\ Indonesia
}

\begin{abstract}
Many of the melinjo chips household industries in Bantul have been operating for a very long time, are still included in the household industry scale, proving that the industry is not developing. This study aims to determine: 1) the entrepreneurial character of the melinjo chips household industry; 2) factors that correlate with entrepreneurial character 3 ) business feasibility of melinjo chips; 4) the relationship between entrepreneurial character and economic performance of the business. This research is a descriptive study conducted with a survey method of 60 respondents in Bantul Regency. The method analysis are using table analysis and regretion analysis The results showed that the entrepreneurial character of the emping melinjo business owner in Bantul being studied were achievement motivation and leadership (quite low), responsive and creative in facing the future (low) and business networks (very low). The character of achievement motivation influences other entrepreneurial characters. The external factor that affects the character of entrepreneurship is government support. The feasibility level of the melinjo chips business is measured by an RC ratio of 1 , a capital productivity level of $3 \%$ and a labor productivity level of 206,800 / HOK. The entrepreneurial character of a broad business network and availability of labor have an effect on the feasibility of an $\mathrm{R} / \mathrm{C}$ business and capital productivity. Internal factors of family support have a negative effect on company performance in labor productivity.
\end{abstract}

\section{Introduction}

Bantul is popular as a producer of melinjo (Gnetum gnemon), which encourages the growth of the melinjo chip processed food industry, which is very popular and has a high economic value. Based on the results of initial observations, many home industries of melinjo chips that have been operating for a very long time are still included in the home industry scale, proving that the industry is not developing; it is interesting to look for the cause. If the cause is known, the prospect and development policy will be pursued.

* Corresponding author: triwarabs@gmail.com 
The sustainability and growth of the processed food industry faces problems including: [1] suboptimal business management skills, [2] availability of raw materials, [3] inefficiency in financing production inputs, [4] inefficiency in marketing; and [5] inefficiency in the use of labor. Of the five problems that are often faced, the most interesting to be studied in terms of business management skills are not yet optimal. Other problems can be solved if the actors have skills in managing their business. Technical skills in processing food, on average, are qualified. The question that arises is whether business management skills are actually influenced by non-technical conditions such as the entrepreneurial spirit and social conditions of industry players? Is this entrepreneurial character correlated with the economic performance of his business?

The entrepreneurial spirit has the meaning: having creativity and certain goals and trying to achieve success in life [15]. In reality, creativity is difficult to realize and if you can realize it, you cannot sell it. Yet in order to be economically useful, being able to sell is very important.

A person's motivation to pursue entrepreneurship in Indonesia is still low. The reasons people turn to the world of entrepreneurship, among others: as a stepping stone while waiting for other job opportunities, or it could be because they are forced to help the family economy [14]. For example, the entrepreneurial character of achievement motivation in the local sago agro food industry is included in the high category with an index value of 70.08. From this value, it can be concluded that local sago agro food industry players have high enthusiasm and commitment, are hard workers, don't give up easily to develop their business [16].

There are significant differences in entrepreneurial attitudes between male and female small industry entrepreneurs; there is a significant relationship between entrepreneurial attitude, age, length of business, education level, gender and family background together on the success of small industrial entrepreneurs, and the largest contribution is the entrepreneurial attitude variable and the education level variable [1].

Individual characteristics that influence the success of the small weaving and embroidery industry in Sumatra are the training and experience of the entrepreneur. They have entrepreneurial traits that stand out in terms of motivation, keen to seize opportunities and self-confidence, with very significant business capabilities in terms of supplying raw materials, market access and availability of capital. However, the success of its business is strongly influenced by the availability of labor, especially its productivity, sales volume and sales growth [2].

The future-oriented character of business actors is a strength to make the business they run can continue to advance in the future [9]. In addition, business actors do not yet fully have high creativity in managing their business, as evidenced by the products produced, there is no difference from year to year [4]. A business that has a strong network will provide knowledge to business actors to manage their business effectively and efficiently, so that business actors have competitiveness [6].

Entrepreneurship is the ability of someone who is dynamic in character who is always looking for opportunities and taking advantage of them to generate added value. Entrepreneurship is all about techniques, methods, systems, and various business strategies that can be learned. Analysis of matters relating to entrepreneurship can be about the character, behavior, attitudes, personality development, group history, as well as the interests, motivations, and ambitions of an entrepreneur in achieving success [12].

Character is a quality that a person has that makes him attractive and attractive, can be a reputation and even an eccentric personality of a person. Character is formed through the journey of an individual's life, and according to Helen Keller, character cannot be developed in pleasure and tranquility, but through experiences of trial and mental suffering that can be strengthened, vision cleared, ambition inspired, and success achieved [15]. 
The characteristics of the entrepreneurial character are described by many experts who are engaged in the field of entrepreneurship. McClelland [15] has the concept of Need for Achievement (N-Ach). A person's attitude and behavior are strongly influenced by the nature and character possessed by that person.

Based on reviews by experts, there are five entrepreneurial characteristics that must be owned by business actors: 1. High motivation, supporting characters: (a) hard worker, (b) never give up, (c) high spirit, (d) high commitment. 2. Orientation to the future, supporting characters: (a) visionary, (b) positive thinking, (c) having broad knowledge 3. Excellent leadership spirit, supporting characters: (a) daring to act, (b) building a strong team good, (c) think and have a big heart, (d) dare to take risks, (e) having mentor, (f) open mind, (g) trust 4. Extensive business network, with the following characteristics: (a) business network, (b) friends, (c) cooperation. 5. Responsive and creative in dealing with change, supporting characters: (a) critical thinking, (b) fun, (c) proactive, (d) creative, (e) innovative, (f) efficient, (g) productive, (h) original.

From this description, the formulation of the research problem is: What is the entrepreneurial character of the melinjo emping home industry in Bantul Regency? What factors correlate with it? Is the home industry of melinjo chips economically viable? Is there a relationship between the entrepreneurial characters of the emping melinjo home industry players with their business performance? So, the research objectives are as follows: to find out the entrepreneurial character of the melinjo emping home industry; knowing the factors that correlate with the entrepreneurial character of the home industry of melinjo chips; determine the feasibility of the home industry (micro) emping melinjo; knowing the relationship between the entrepreneurial character of the melinjo emping household business actor and the economic performance of his business.

\section{Methodology}

The basic method used in this research is the descriptive method, in order to accurately describe the circumstances and characteristics of an individual who is the object of research. Descriptive methods describe the relationship between phenomena, test hypotheses, and make implications of a problem to be solved. That is intended for careful measurement of social phenomena. In accordance with a statement which states that descriptive analysis is a statistic used to analyze data by describing or describing previously collected data as it is without intending to make conclusions [13].

The research was conducted in Bantul Regency, DIY, based on previous research that in that area there were the most home industries for processed melinjo chips. Samples were determined by Simple Random Sampling. To determine the number of samples, it is carried out on a quota basis based on the consideration that the processed food business has a business following the fixed proportion input/output model; the same input volume will produce the same amount of output for similar businesses. Then the nature of the company as a population is homogeneous and the number of samples can be representative without having to be determined proportionally. The number of samples is determined as 60 samples

Data collection includes secondary data and primary data. Secondary data were obtained from government agencies that handle MSMEs (Deperindagkop). Primary data is obtained from business actors through direct observation in the field with interview techniques using a list of questions/questionnaires that have been prepared. The number of samples was determined to be 60 players from the melinjo emping home industry. Meanwhile, for general information and policies, key informants were interviewed from the provincial level to the district level. 
Primary data includes:

1. Supporting indicators for the 5 entrepreneurial characters of business actors include, among others: a. High motivation, b. Future orientation, c. Excellent leadership spirit, d. Extensive business network, e. Responsive and creative in facing change

2. Internal environmental factors include: (a) education level, (b) business experience, (c) extroverted nature of business actors.

3. Economic environmental factors consist of: (a) business profits, (b) input market, (c) output market.

4. Physical environmental factors consist of: (a) availability of transportation infrastructure, (b) development (innovation) of production technology, (c) development of information and communication technology.

5. Social environmental factors consist of: (a) family support, (b) community support, (c) government support, (d) product diversity.

6. Institutional environmental factors include: (a) financial institutions (related to credit), (b) business groups, (c) higher education institutions,

7. Management capacity indicators consist of: (a) planning, (b) organizing, (c) implementation, (d) supervision.

8. Business/production process indicators include: (a) provision of raw materials and additional materials, (b) processing, (c) packaging, (d) storage, (e) marketing

9. Company performance indicators: (a) labor productivity, (b) $\mathrm{R} / \mathrm{C}$, (c) capital productivity.

Calculation of company performance is based on the concepts of cost, revenue, profit and business feasibility. Cost in a company is the economic value of all the inputs needed, which can be estimated and can be measured to produce a product. Meanwhile, the total cost according to [10] means the lowest total expenditure required to produce each level of output. Meanwhile, according to [3] and [8], the total cost (TC = Total Cost) is the total number of explicit costs and implicit costs. TC $=$ TEC + TIC.

Revenue is the payment received by the company from the sale of goods or services. While the total revenue according to [7] is the result of multiplying the number of goods sold with the price of the goods (the value of which depends on the number of goods).

Profit is total revenue minus total cost. So, profit is determined by two things, namely revenue and costs. If the change in revenue is greater than the change in the cost of each output, the profit received will increase. If the change in revenue is smaller than the change in costs, the profit received will decrease. Thus, the profit will be maximized if the change in revenue equals the change in costs.

Business efficiency can also be calculated from the comparison between the amount of revenue and the costs incurred for production, by using the $\mathrm{R} / \mathrm{C}$ ratio (Revenue Cost Ratio) This step also use by [17] to compare the Oyster Mushroom Finance analyses in Highland. In calculating the analysis, it is better to divide the $\mathrm{R} / \mathrm{C}$ into two, namely the $\mathrm{R} / \mathrm{C}$ which uses the real costs incurred by the entrepreneur and the $\mathrm{R} / \mathrm{C}$ which calculates all costs, both real costs incurred, and non-real costs incurred [11]. The feasibility of the business can be seen from the value of the $\mathrm{RC}$ ratio, capital productivity. By Criteria:

$\mathrm{R} / \mathrm{C}>1=$ Business is feasible to run.

$\mathrm{R} / \mathrm{C}<1=$ Business is not feasible to run.

$\mathrm{R} / \mathrm{C}=1=$ Break-even business or not feasible to run.

$$
P M=\frac{N R-\text { rent your own place }- \text { TKDK cost }}{T E C} \times 100 \%
$$


Information:

$\mathrm{PM}=$ Capital productivity

$\mathrm{NR}=$ Revenue

TKDK $=$ Labor in the family

TEC $=$ Total Explicit Cost

By Criteria:

a) Capital productivity $>$ bank loan interest rate, then the business can be said to be feasible to run.

b) Capital productivity < interest rate on bank loans, then the business can be said to be unfit for business.

Analysis of the relationship between entrepreneurial character and household economic performance of emping melinjo measured by Spearman's Rank correlation. Spearman Rank correlation formula used:

$$
r_{s}=1-\frac{6 \sum d^{2} i}{n\left(n^{2}-1\right)}
$$

Information:

$\mathrm{r}_{\mathrm{s}}=$ correlation coefficient of sperm rank

$\mathrm{d}=$ Difference in ranking between variables

$\mathrm{n}=$ Number of samples or data

\section{Results and discussions}

The emping melinjo businesses that were selected as samples have a length of business ranging from 2-35 years with an average length of business of 18 years. The youngest business actor is 30 years old and the oldest is 65 years old. The education level of the respondents is mostly elementary school (40 people) or $66.7 \%$, junior high school 15 people $(25 \%)$ and high school at least, not reaching $10 \%$ (5 people). The location of the melinjo chips business is about $15 \mathrm{~km}$ from the Bantul district government center and about $10 \mathrm{~km}$ from the provincial government center, the number of products ranges from 30 to $1000 \mathrm{~kg}$ of chips per month. The costs required are between IDR 1.034 million - IDR 30.18 million per month, with an income of around IDR 1.15 million - IDR 50 million/month. The profit that can be generated ranges from IDR 117,000 - IDR 18 million.

Five major categories of entrepreneurial character that must be possessed by individual entrepreneurs are: (1) Achievement motivation, this character is measured based on the following characteristics: (a) extroversion, (b) need for achievement, (c) implementation (having high enthusiasm), (d) supervision (have a high commitment). (2) Forward orientation, this characteristic is measured by the following characteristics: (a) market orientation (visionary), (b) having skills in business, (c) having extensive knowledge in the development of production technology. (3) Having a strong leadership spirit. superior, by measuring the following characteristics: (a) independent (dare to act), (b) build a good team (organization), (c) dare to take risks, (d) have management capacity, (e) self-confidence. (4) Having an extensive business network, by measuring the conditions of: (a) business groups, (b) cooperation with financial institutions, (c) cooperation with higher education institutions. (5) Responsive and creative in facing change, the measured characters include:

(a) Profit (productivity) development, (b) Information technology utilization development

(c) proactive in product diversification (innovative), (d) Creativity. 
For the first entrepreneurial character, the achievement motivation of respondents has a total score of 8.92; the total score that may be achieved is 20 in the fairly low category. The second entrepreneurial character is the character of future orientation. The entrepreneurial character of future orientation is still low, only having a score of 6.72 with a total maximum score that can be achieved 15. The third entrepreneurial character is the leadership spirit. This character reaches $51 \%$ capacity, (quite low) based on the average number of points which only reaches 12.75 out of a maximum of 25 points. The fourth entrepreneurial character is the ownership of a business network, which is owned by the respondent. The entrepreneurial character of business network ownership owned by respondents is also still very low with a new capacity of $28.5 \%$, based on the average number of points collected which only reached 4.27 out of a maximum of 15 points. The fifth entrepreneurial character is responsive and creative in dealing with change. The entrepreneurial character of responding to changes that exist in respondents is also still low, only reaching $40 \%$ capacity, based on the average number of points obtained by respondents only reaching 8.87 out of a maximum of 20 points.

Based on the results of the analysis of the entrepreneurial character of the respondents as business actors, it can be said that the emping melinjo household business in Bantul is still running as it is seen from its predecessor. Has not developed in accordance with the progress of the business world. It has not been strongly touched by advances in information technology and production technology which will certainly have an impact on the progress of its business in terms of efficiency which can improve its business performance.

According to the result of the research, if the weak character of the business network in the melinjo chips industry must be handled seriously so that business actors have many relationships to develop their businesses. This statement is supported by a study on business networks in MSMEs in Boyolali. In the study it was said that MSMEs must build and establish relationships with financial institutions, suppliers, and other intermediaries so that these businesses can develop. The MSME business network in Boyolali is not perfect so it must be improved (5).

In this study, total cost 3,621,750.41 IDR and total revenue is 4,140,060.32 IDR, business feasibility is calculated based on $\mathrm{R} / \mathrm{C}$ (revenues obtained are compared with costs incurred). (11). The $\mathrm{R} / \mathrm{C}$ is 1.14 The $\mathrm{R} / \mathrm{C}$ values achieved by respondents ranged between 0.64 (lowest) and 1.77 the highest, with an uneven distribution, mostly at very low $\mathrm{R} / \mathrm{C}$ levels with an average $\mathrm{R} / \mathrm{C}$ value of 1.14 . This could be due to inefficiency at every stage of production, for example in purchasing raw materials and additional production materials, because of small capital, the purchase of raw materials and additional materials is also in small quantities, as long as it can be for temporary production.

So that it can be said that every time you go into production you have to buy these materials, so the price you have to pay can be higher, small-scale purchases are definitely more expensive per unit than if you buy on a large scale. Multiple purchases on a small scale will also increase the accumulation of transportation costs, also related to the distance from the business location to the input market. In calculating the labor costs to be paid there is a possibility of inefficiency, because in paying the wages it is not in accordance with the working hours per day. Workers who stop working prematurely are still paid according to the day's wages.

The next performance indicator of the processed food home industry to be analyzed is labor productivity. To determine the level of labor productivity, it is calculated based on the amount of profit obtained compared to the number of workers used, so that the amount of profit is obtained for each use of 1 man days. As for the value of the average labor productivity of IDR 206,800 with an uneven distribution, most of them are at very low productivity levels and some are negative. This is because the price of melinjo seeds as a 
raw material often suddenly rises, while sales of the emping produce cannot be increased, so that there is often low revenue.

To determine the relationship between the entrepreneurial character of the emping melinjo household business actor and the economic performance of his business, regression analysis was carried out. The results of the first regression analysis show that the factors that have a significant effect on company performance through the $\mathrm{R} / \mathrm{C}$ dimension are business network factors and the availability of labor. In general, the character of the business network ownership of the respondents is still not wide, with an average total point of only 4.26 out of a maximum of 15 points, or only about $28.40 \%$ of the character capacity owned by the respondent, so it must be increased. The results of the regression analysis provide information that there is also a significant influence of the labor availability factor. This is probably because a business network that is not extensive can lead to inefficient marketing costs. Meanwhile, the availability of labor that is only at a sufficient level (3.26 points out of a total of 5) will have an effect on labor costs; if a lot of labor is available wages can be further suppressed.

The result of the next regression analysis is that the factors that affect business performance through capital productivity are business network factors and the availability of labor as well. This is because the effect of the limited business network and the inefficiency of labor costs will lead to cost inefficiency even though it is difficult for producers to increase the selling price of their products, so both of these factors must continue to be improved so that efficiency increases, and income will also increase. Thus, it is expected that capital productivity can also be higher.

The next regression analysis is that there is a significant but negative effect (regression coefficient $-0,389$ ) of family support on labor productivity in the emping melinjo business. This is probably due to the very low factor of family support for the business (points achieved 2.2 of the total 15 points). Therefore, business actors must devote full time to their business performance, even though the profits obtained are low, resulting in low labor productivity.

\section{Conclusion}

On average, the five entrepreneurial characters possessed by the respondents are: a) the character of achievement motivation is quite low, b) the character of future orientation is low, c) the character of the leadership spirit is quite low, d) the character of ownership of business networks is very low, e) the character of responsive and creative facing change is still low.

The entrepreneurial character that plays the most important role because of its influence on other characters is the character of achievement motivation. This character has a strong influence on the character of the leadership spirit, responsive and creative character in dealing with change, and mutual influence with external factors of government support

Low R/C rate (1). Capital productivity 0.03 , labor productivity IDR 206,800/man days.

The influence of the entrepreneurial character of the processed food home industry on their business performance: the entrepreneurial character of a broad business network and the availability of labor have a significant effect on the company's performance through the $\mathrm{R} / \mathrm{C}$ route and capital productivity. The internal factor of family support has a significant negative effect on company performance through labor productivity. 


\section{References}

1. Anggraini, N,. "Perbandingan Sikap Kewirausahaan Diantara Pengusaha Industri Kecil Berhasil, Statis dan Tidak Berhasil; Studi Pada Perkampungan Industri Kecil Pulogadung, Jakarta Timur..Tesis. Program Studi Manajemen, Fakultas Ekonomi Universitas Indonesia. Jakarta, (2008).

2. Dalimunthe, R. Pengaruh Karakteristik Individu, Kewirausahaan, Gaya Kepemimpinan Terhadap Kemampuan Usaha Serta Keberhasilan Industri Tenun di Sumatra.Disertasi Program Studi Ilmu Ekonomi Universitas Airlangga, (2002)

3. Dewi, E. T. Analisis Pendapatan Dan Kesejahteraan Petani Karet Rakyat Di Desa Batu Merah Kecamatan Lampihong Kabupaten Balangan. Jurnal Frontier Agribisnis, 3(4), 147-153, (2019).

4. Ekasari, N., \& Nurhasanah, N, Pengaruh Karakteristik Wirausaha Terhadap Keberhasilan Usaha Perabot Rumah Tangga Di Kecamatan Jambi Timur Kota Jambi. Jurnal Sains Sosio Humaniora, 1(1), 38-56, (2017).

5. Hendriyanto, A., Analisis Pengaruh Jaringan Usaha dan Inovasi Terhadap Kinerja UMKM. Jurnal Ilmu Manajemen Dan Akuntansi Tarapan, 6(1), 44-49, (2015).

6. Irawan, D, Peningkatan Daya Saing Usaha Micro Kecil dan Menengah Melalui Jaringan Usaha. Jurnal Ilmiah Manajemen, b (2), 103-116, (2020).

7. Nicholson, W, "Teori Makro Ekonomi: Prinsip Dasar dan Perluasan.Terjemahan Daniel Wijaya, Bina Rupa Aksara, Jakarta, (1995).

8. Rahmawati, N., Triyono, \& Zalfa, H. L, Analisis Resiko Usahatani Padi Semi Organik di Kebonagung Kecamatan Imogiri Kabupaten Bantul. Prosiding Seminar Nasional Pertanian Peternakan Terpadu Ke-3 ISBN, 439-449, (2015).

9. Rajagukguk, Z. Karakteristik Kewirausahaan Pengusaha Kecil dan Strategi Pengembangan Usahanya di Masa Depan: Studi Kasus Pengusaha Pakaian Jadi di Depok. Jurnal Kependudukan Indonesia, 11(1), 49-62, (2016).

10. Samuelson, P. and W. Nordhaus, Economics, Fifteenth International Edition, New York: McGraw Hill, (2003).

11. Soekartawi, Teori Ekonomi Produksi dengan Pokok Bahasan Analisisi Fungsi Produksi Cobb-Douglas. Rajawali Press, Jakarta, (2016).

12. Subanar, Harimurti, .Manajemen Usaha Kecil.BPFE Yogyakarta, ( 2009).

13. Sugiono, Metode Penelitian Kuantitatif, Kualitatif, dan R\&D. Alfabeta, (2014).

14. Suparyanto, Kewirausahaan.Konsep dan Realita pada Usaha Kecil.Penerbit Alfabeta Bandung, (2012).

15. Suryana, Y, dan Bayu K, Kewirausahaan, Pendekatan Wirausahawan Sukses.Prenada Media Group, Jakarta, (2011).

16. Timisela, N. R., Leatemia, E. D., \& Polnaya, F. F., Analisis Kewirausahaan Agroindustri Pangan Lokal Sagu. Matrik: Jurnal Manajemen, Strategi Bisnis Dan Kewirausahaan, 11(2), 166, (2017).

17. N. Rahmawati and Marbudi, E3S Web Conf. 232, 01012 (2021). 